\title{
The Effect of Microorganisms and Seasonal Factors on the Isotopic Composition of Particulate Organic Carbon from the Black Sea
}

\author{
M. V. Ivanov*, A. Yu. Lein**, Yu. M. Miller*, S. K. Yusupov*, \\ N. V. Pimenov*, B. Wehrli***, I. I. Rusanov*, and A. Zehnder*** \\ *Institute of Microbiology, Russian Academy of Sciences, pr. 60-letiya Oktyabrya 7, k. 2, Moscow, 117811 Russia \\ **Shirshov Institute of Oceanology, Russian Academy of Sciences, Nakhimovskii pr. 36, Moscow, 117218 Russia \\ ***Swiss Federal Institute for Environmental Science and Technology (EAWAG), Switzerland
} Received February 29, 2000

\begin{abstract}
The isotopic composition of particulate organic carbon (POC) from the Black Sea deep-water zone was studied during a Russian-Swiss expedition in May 1998. POC from the upper part of the hydrogen sulfide zone (the C-layer) was found to be considerably enriched with the ${ }^{12} \mathrm{C}$ isotope, as compared to the $\mathrm{POC}$ of the oxycline and anaerobic zone. In the C-layer waters, the concurrent presence of dissolved oxygen and hydrogen sulfide and an increased rate of dark $\mathrm{CO}_{2}$ fixation were recorded, suggesting that the change in the POC isotopic composition occurs at the expense of newly formed isotopically light organic matter of the biomass of autotrophic bacteria involved in the sulfur cycle. In the anaerobic waters below the C-layer, the organic matter of the biomass of autotrophs is consumed by the community of heterotrophic microorganisms; this results in weighting of the POC isotopic composition. Analysis of the data obtained and data available in the literature allows an inference to be made about the considerable seasonable variability of the POC $\delta^{13} \mathrm{C}$ value, which depends on the ratio of terrigenic and planktonogenic components in the particulate organic matter.
\end{abstract}

Key words: carbon isotope fractionation, bacterial chemosynthesis, particulate organic carbon, the Black Sea.

The production of organic matter by autotrophic and methanotrophic bacteria and the effect of this process on the isotopic composition of particulate organic carbon (POC) have been studied in less detail than the role of these bacteria in the oxidation of reduced carbon, sulfur, and nitrogen compounds, which occurs at the interface of the aerobic and anaerobic zones. In most bodies of water, this interface occurs either on the surface of bottom sediments or in their thickness $[1,2]$. This fact hinders elucidation of the role of particular microbial groups in the processes of organic matter production and consumption, because the changes in redox conditions and in the chemical composition of the pore waters occur within a thin sediment layer.

Meromictic lakes, where the chemocline spans tens of centimeters or even several meters, and, especially, the central, deep part of the Black Sea, where this zone spans tens of meters $[3,4]$, are much more convenient investigation objects.

Numerous experiments performed with the use of ${ }^{14} \mathrm{C}$ bicarbonate showed that organic matter production in the Black Sea chemocline reaches several $\mathrm{mg} /\left(\mathrm{m}^{3}\right.$ day) [4-6]. This process involves aerobic sulfur-oxidizing and nitrifying bacteria, as well as anaerobic photosynthetic sulfur bacteria $[7,8]$. Our experiments performed with the use of ${ }^{14} \mathrm{CH}_{4}$ demonstrated the involvement of methanotrophs in the production of organic matter (biomass and water-soluble organic exometabolites) in the chemocline $[6,9]$.

Laboratory experiments with aerobic sulfur-oxidizing, nitrifying, and methanotrophic bacteria, as well as with anaerobic photosynthetic bacteria, demonstrated that the synthesis of the biomass of these bacteria is accompanied by notable fractionation of the stable carbon isotopes ${ }^{12} \mathrm{C}$ and ${ }^{13} \mathrm{C}[10-14]$. Enrichment of the biomass of the nitrifying bacterium Nitrosocystis oceanus and the phototrophic bacterium Thiocapsa reseopersicina with the ${ }^{12} \mathrm{C}$ isotope was, respectively, 35.9 and $32.2 \%$ relative to the bicarbonate of the cultivation medium [11, 10]. Methanotrophic bacteria can produce biomass that is still lighter isotopically: the organic matter of the bacterial films covering the carbonate constructions near the cold seeps at the Black Sea floor is characterized by a $\delta^{13} \mathrm{C}$ value of -75.6 to $-83.8 \%$ o [14].

The above two groups of facts-the intense production of secondary (bacterial) organic matter in the Black Sea chemocline and the notable fractionation of stable carbon isotopes in the course of synthesis of the biomass of autotrophic and methanotrophic bacteriaurged two research teams to examine the isotopic composition of POC in an attempt to reveal indications of 
the bacterial fractionation of carbon isotopes. Samples of POC were taken from various horizons of the Black Sea water column $[15,16]$.

Thus, 22 samples of POC were taken from depths from 0 to $120 \mathrm{~m}$ at the end of May 1988 during the expedition on board the American research vessel Knorr [15]. In the water layer from 0 to $32 \mathrm{~m}$, the $\delta^{13} \mathrm{C}$ values ranged from -25.0 to $-25.6 \%$; in the water layer from 32 to $63 \mathrm{~m}$, the $\delta^{13} \mathrm{C}$ value increased to $-21.8 \%$. Only in one sample taken from a depth of $48 \mathrm{~m}$ was the POC enriched with the ${ }^{12} \mathrm{C}$ isotope $\left(\delta^{13} \mathrm{C}=-28.3 \%\right.$ ). In the hydrogen sulfide zone, beginning at a depth of $80 \mathrm{~m}$, the average $\delta^{13} \mathrm{C}$ value was $-23.1 \%$ o. Thus, no anomaly of negative $\delta^{13} \mathrm{C}$ values was revealed in the upper part of the sulfide zone [15].

More detailed studies of the isotopic composition of POC were carried out by L.A. Kodina and coworkers, who used samples of POC taken at five stations during the 26th expedition on board the research vessel Vityaz' in September-October 1992 [16]. At one of the stations, a complete vertical distribution profile (0-2000 m) of $\delta^{13} \mathrm{C}$ values was obtained. At three other stations, samples were taken at 10 to $70 \mathrm{~m}$ intervals from the oxygenated zone and the upper part of the hydrogen sulfide zone to a depth of 120-170 m [16].

At all stations, a regular change in the $\delta^{13} \mathrm{C}$ value with depth was observed, from $\delta^{13} \mathrm{C}=-21.5 \ldots-22.6 \%$ o at the surface to $\delta^{13} \mathrm{C}=-25.3 \ldots-26.7 \%$ at a depth of $120-170 \mathrm{~m}$. The authors claim that the lowest $\delta^{13} \mathrm{C}$ values were recorded in water samples taken near the upper boundary of the hydrogen sulfide layer and believe that this is proof of the isotopic effect of chemosynthesis at a level of $-4 \ldots-5 \%$ [16]. The authors are not embarrassed by the facts that, at two stations ( 3794 and 3801), "the effect of chemosynthesis" was found in water samples taken 15-20 m below the upper boundary of the hydrogen sulfide layer and, at station 3804 , isotopically light POC occurred $25 \mathrm{~m}$ below this boundary; only at station 3818 was isotopically light POC actually found at the upper boundary of the hydrogen sulfide layer.

Since Kodina et al. obtained no evidence in favor of the occurrence of chemosynthesis in the water samples analyzed (neither direct evidence that could have been obtained in experiments with ${ }^{14} \mathrm{CO}_{2}$ nor even indirect evidence in the form of data on the distribution of donors and acceptors required by chemoautotrophs), the statement of these authors about the influence of chemosynthesizing bacteria on the isotopic composition of POC [16] is unsubstantiated.

Thus, despite the theoretic possibility of changes in the isotopic composition of POC at the expense of the secondary production of the organic matter of bacterial biomass and the two attempts to test this possibility for the Black Sea, the question remains unresolved.

The aim of the present work was to study the distribution of the stable ${ }^{12} \mathrm{C}$ and ${ }^{13} \mathrm{C}$ isotopes in the Black Sea POC and the effect of microorganisms on the iso- topic composition of POC. To solve this problem, in all of water samples we performed, in addition to the analysis of POC, a complex of hydrochemical and microbiological analyses and also determined the rates of a number of microbial processes by the method of shortterm incubation of samples with radiolabeled substrates $\left(\mathrm{NaH}^{14} \mathrm{CO}_{3} ;{ }^{14} \mathrm{CH}_{4} ;{ }^{14} \mathrm{CH}_{3} \mathrm{COONa} ; \mathrm{Na}_{2}{ }^{35} \mathrm{SO}_{4}\right)$ under in situ conditions.

A detailed description of the methods for hydrochemical and microbiological analyses and the results obtained can be found in the work by Pimenov et al. [6].

\section{MATERIALS AND METHODS}

Water samples were taken in the first half of May 1998 during the Russian-Swiss expedition on board the research vessel Professor Vodyanitskii within the framework of the INTAS-RFBR project "Microbiological and Biogeochemical Processes at the Boundary of Aerobic and Anaerobic Zones in the Black Sea." Samples were taken along the entire vertical profile at three stations on the northwestern shelf $(1 \mathrm{~A}, 1 \mathrm{~B}, 2)$, at station 3 located on the continental slope, and at three stations $(4,5$, and 6$)$ in the central part of the sea (Fig. 1). In addition, in this work, we use the results of our determinations of $\delta^{13} \mathrm{C}_{\text {org }}$ values in POC samples collected at northwestern shelf stations during an expedition in the middle of May 1997 (Fig. 1).

In the boundary zone between aerobic and anaerobic waters, sampling was performed at 5-m intervals. Samples were taken with 10-1 Niskin bottles (the Rosette complex).

Samples of POC were obtained by filtering water samples (up to 30 l) through GF/F (Whatman) fiberglass filters. Filtration was performed aboard the ship immediately after water sampling.

In the laboratory at the Institute of Microbiology, the isotopic composition of carbon was analyzed by the sample-standard method on an MI-1201V mass spectrometer equipped with a two-channel injection system.

A set of laboratory standards calibrated relatively to the PDB carbon standard was used:

$$
\delta^{13} \mathrm{C}=\left[\left(R_{\mathrm{st}}-R_{\mathrm{sam}}\right) / R_{\mathrm{st}}-1\right] \times 10^{-3} \% \text { o, }
$$

where $R_{\text {sam }}$ and $R_{\text {st }}$ are the ${ }^{13} \mathrm{C} /{ }^{12} \mathrm{C}$ ratios for the sample and standard, respectively. The $R_{\text {sam }}$ and $R_{\text {st }}$ values were calculated on a computer, which also controlled gas flows directed in turn into the ionic source of the mass spectrometer.

To determine the amount of organic carbon and its isotopic composition, a portion of the fiberglass filter with the trapped POC was ground and poured, together with $\mathrm{CuO}$ powder roasted at $600^{\circ} \mathrm{C}$, into a Pyrex glass ampule roasted at $900^{\circ} \mathrm{C}$, which was then vacuumed to a residual pressure of $10^{-2} \mathrm{mmHg}$ and sealed.

Combustion of organic matter to $\mathrm{CO}_{2}$ was performed in a box furnace at $500^{\circ} \mathrm{C}$ for $18 \mathrm{~h}$. After that, 


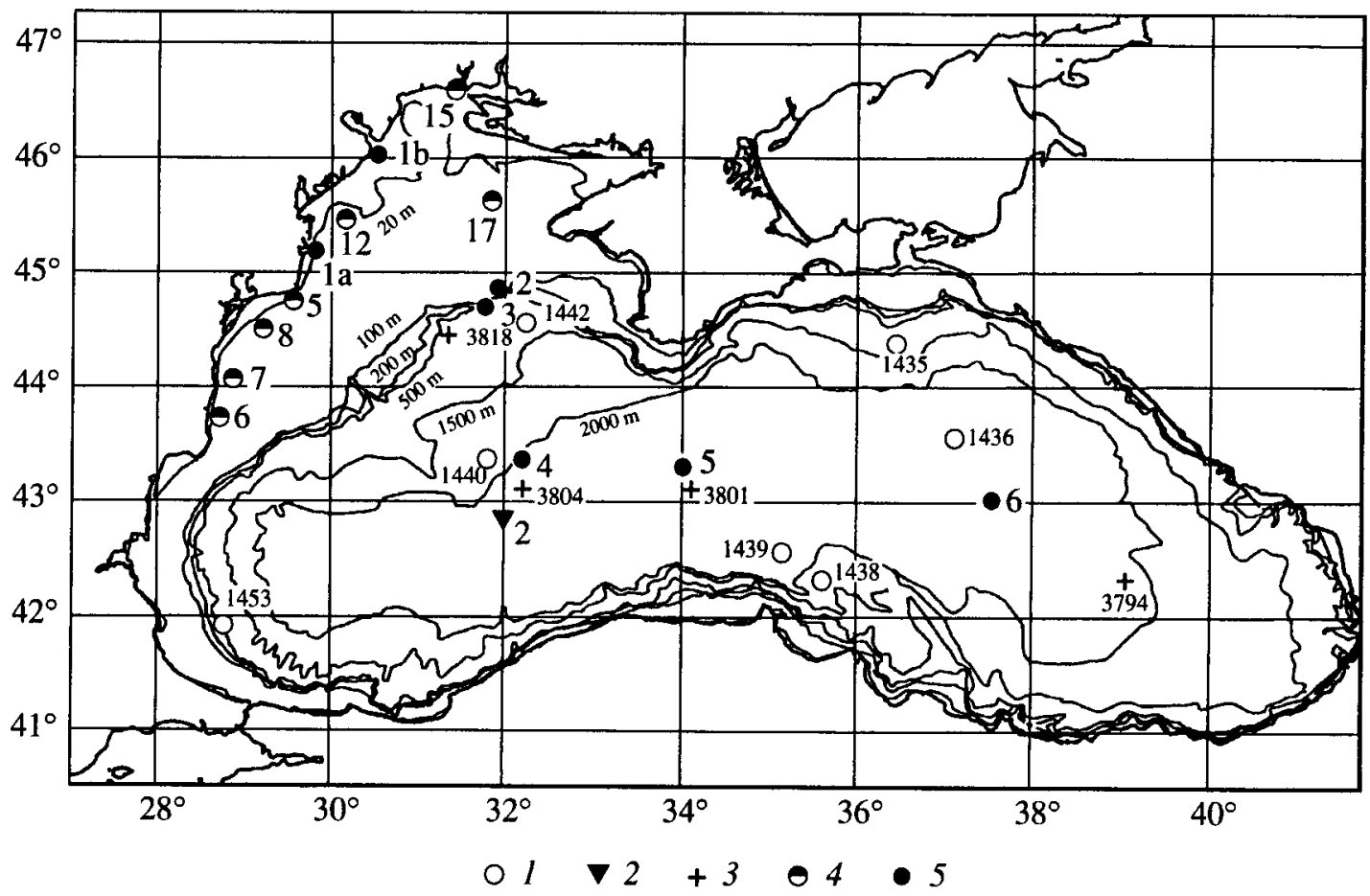

Fig. 1. Scheme showing the location of stations where POC samples were taken: 1, stations explored by Deuser in March-April 1969 [18]; 2, stations explored by the Knorr expedition at the end of May 1988 [15]; 3, stations explored by the Vityaz' expedition in September-October 1992 [16]; 4, stations explored by our expedition in May 1997; 5, stations explored by our expedition at the beginning of May 1998.

the ampule was opened under vacuum and $\mathrm{CO}_{2}$ was collected in a side arm cooled with liquid nitrogen. After removal of water vapor and gaseous admixtures, $\mathrm{CO}_{2}$ was analyzed on a mass spectrometer. The error of $\delta^{13} \mathrm{C}$ determination was $\pm 0.2 \%$.

The method for determination of the amount of organic carbon from the amount of $\mathrm{CO}_{2}$ produced is based on the linear dependence of the mass spectrometric peak on the partial pressure of $\mathrm{CO}_{2}$ in the gas injection system. As a standard, we used glucose, which contains $40 \%$ carbon. The amount of carbon in the sample $(P)$ was calculated by the formula

$$
P=\left(V_{\mathrm{sam}} \times m\right) /\left(V_{\mathrm{gl}} \times 0.4\right), \mathrm{mg},
$$

where $V_{\mathrm{sam}}$ and $V_{\mathrm{g} 1}$ are the intensities (in millivolts) of mass spectrometric peaks of the 44 mass unit for the sample and glucose, respectively, and $m$ is the mass of glucose in milligrams.

\section{RESULTS}

The $\delta^{13} \mathrm{C}$ values in POC samples taken at the deepsea stations 3-6 (Fig. 1) are presented in Tables 1-4. The $\delta^{13} \mathrm{C}$ values determined at the three stations on the northwestern shelf are shown in Table 5, which also presents the variation ranges and average values of the POC $\delta^{13} \mathrm{C}$ for five hydrochemical zones of the deep part of the sea, successively taking turns with depth.
In Tables 1-4, the content of POC and some hydrochemical parameters are presented for each sample investigated. It can be seen that at all three stations located in the western part of the sea, the amount of $\mathrm{POC}$ ranged from 610 to $1617 \mu \mathrm{g} / \mathrm{l}$ (an exception was the 150-m horizon at station 4, containing $2667 \mu \mathrm{g} P O C / 1)$. Considerably higher amounts of POC were found at station 6, located in the central part of the eastern halistase. At this station, maximum concentrations of POC (1430-2450 $\mu \mathrm{g} / \mathrm{l})$ were found in the upper part of the hydrogen sulfide zone (Table 4, Fig. 2).

Analysis of the variations of the POC $\delta^{13} \mathrm{C}$ value along the vertical profile, performed for separate stations (Tables 1-4) and for the deep part of the sea as a whole (Table 5), allows the following conclusions to be made.

The isotopically lightest POC occurs in the upper 40-m layer, where the dissolved oxygen concentration exceeds $230 \mu \mathrm{M}$.

The average $\delta^{13} \mathrm{C}$ value of $\mathrm{POC}$ in this zone is $-28.0 \%$; the isotopically lightest organic matter occurs in the central part of the deep-sea basin (st. 4-6), where, in some samples, the $\delta^{13} \mathrm{C}$ value reached $-29.2 \%$ (st. 6 , a depth of $30 \mathrm{~m}$ ) and even $-30.2 \%$ (st. 4 , a depth of $35 \mathrm{~m}$ ). The POC of the upper hydrochemical zone of st. 3, located at the northwestern continental slope (Fig. 1), was notably less enriched with the ${ }^{12} \mathrm{C}$ isotope. The $\delta^{13} \mathrm{C}$ value of POC from a depth of $30 \mathrm{~m}$ (Table 1) was 
Table 1. Hydrochemical parameters of the water column and the isotopic composition of POC at station $3\left(44^{\circ} 41^{\prime} 08^{\prime \prime} \mathrm{N}\right.$, $31^{\circ} 48^{\prime} 40^{\prime \prime} \mathrm{E}$; depth, $592 \mathrm{~m}$ )

\begin{tabular}{c|c|c|c|c|c|c|c}
\hline $\begin{array}{c}\text { Hydrochemical } \\
\text { zone }\end{array}$ & Depth, $\mathrm{m}$ & $\mathrm{O}_{2}, \mu \mathrm{M}$ & $\mathrm{H}_{2} \mathrm{~S}, \mu \mathrm{M}$ & $\mathrm{NH}_{4}^{+}, \mu \mathrm{M}$ & $\mathrm{NO}_{3}^{-}, \mu \mathrm{M}$ & $\begin{array}{c}\text { Particulate } \\
\text { matter, } \mu \mathrm{g} / 1\end{array}$ & $\delta^{13} \mathrm{C}, \%$ o \\
\hline I & 30 & 284 & 0 & 0 & 0.015 & 1033 & -24.2 \\
II & 130 & 174 & 0 & 0 & 3.381 & 610 & -22.8 \\
& 170 & 18 & 0 & 0 & 3.315 & 807 & - \\
III & 175 & 11 & 0 & 0 & 1.156 & 838 & -25.8 \\
IV & 180 & 1 & Traces & 0 & 0.45 & 622 & -25.9 \\
& 185 & Traces & 2.2 & 7.390 & 0.004 & 644 & -27.1 \\
V & 190 & Traces & 4.5 & 31.191 & 0 & 800 & -27.0 \\
& 195 & 0 & 8.9 & 40.825 & 0 & 724 & -26.5 \\
& 200 & 0 & 13.4 & 44.792 & 0 & 870 & -24.9 \\
& 210 & 0 & 22.3 & 83.044 & 0 & 1133 & -25.3 \\
& 220 & 0 & 29 & 84.744 & 0 & - & - \\
& 250 & 0 & 31.2 & - & - & 1223 & -26.7 \\
& 400 & 0 & 98.2 & 424.887 & 0 & 995 & -24.2 \\
& 500 & 0 & 138.4 & 613.474 & 0 & 989 & -25.4 \\
\hline
\end{tabular}

Table 2. Hydrochemical parameters of the water column and the isotopic composition of POC at station $4\left(44^{\circ} 20^{\prime} 23^{\prime \prime} \mathrm{N}\right.$, $32^{\circ} 09^{\prime} 54^{\prime \prime}$ E; depth, 1998 m)

\begin{tabular}{c|c|c|c|c|c|c|c}
\hline $\begin{array}{c}\text { Hydrochemical } \\
\text { zone }\end{array}$ & Depth, $\mathrm{m}$ & $\mathrm{O}_{2}, \mu \mathrm{M}$ & $\mathrm{H}_{2} \mathrm{~S}, \mu \mathrm{M}$ & $\mathrm{NH}_{4}^{+}, \mu \mathrm{M}$ & $\mathrm{NO}_{3}^{-}, \mu \mathrm{M}$ & $\begin{array}{c}\text { Particulate } \\
\text { matter, } \mu \mathrm{g} /\end{array}$ & $\delta^{13} \mathrm{C}, \%_{0}$ \\
\hline I & 35 & - & 0 & 0 & 0.068 & 943 & -30.2 \\
II & 40 & 238 & 0 & 0 & 0.906 & 1030 & -28.5 \\
& 45 & 150 & 0 & 0 & 1.426 & - & - \\
& 65 & 22 & 0 & 0 & 1.937 & 712 & -27.3 \\
& 90 & 0 & 0 & 0 & 0.322 & 904 & -26.2 \\
III & 100 & 0 & 0 & 9.280 & 0.004 & 852 & -26.7 \\
IV & 105 & 0 & Traces & 28.768 & 0.004 & 760 & -27.0 \\
& 110 & 0 & 4.5 & 47.851 & 0 & 915 & -27.2 \\
V & 115 & 0 & 6.6 & 79.657 & 0 & 1221 & -28.4 \\
& 120 & 0 & 8.9 & 91.642 & 0 & 935 & -27.2 \\
& 125 & 0 & 11.1 & 96.354 & 0 & - & - \\
& 135 & 0 & - & 121.18 & 0 & 1061 & -25.5 \\
& 155 & 0 & - & 169.273 & - & 2667 & -24.8 \\
& 200 & 0 & 44.6 & 235.922 & - & 711 & -25.9 \\
& 500 & 0 & 156.2 & 625.592 & - & 1458 & -25.7 \\
& 1700 & 0 & 290.2 & - & - & 709 & -26.2 \\
\hline
\end{tabular}

$-24.2 \%$; i.e., it was almost equal to that of the isotopically heaviest POC samples taken on the northwestern shelf (see Table 5).

Using example of st. 4 and 6 (Tables 2 and 4), it is seen that, even within the upper 40 -m layer of Black Sea water, POC becomes isotopically heavier with depth. This trend persists in the waters of the second hydrochemical zone (the oxycline). As a result, the average $\delta^{13} \mathrm{C}$ value of POC in this zone is by almost 2\%o greater than in the upper hydrochemical zone (Table 5).

The average value of $\delta^{13} \mathrm{C}$ of the POC of the uppermost part of the zone of coexistence of $\mathrm{H}_{2} \mathrm{~S}$ and $\mathrm{O}_{2}$ (the so-called $\mathrm{C}$-layer), formally speaking, suggests that the $\mathrm{POC}$ is further enriched with the ${ }^{12} \mathrm{C}$ isotope: the aver- 
Table 3. Hydrochemical parameters of the water column and the isotopic composition of POC at station $5\left(43^{\circ} 14^{\prime} 92^{\prime \prime} \mathrm{N}\right.$, $34^{\circ} 00^{\prime} 11^{\prime \prime} \mathrm{E}$; depth, $2172 \mathrm{~m}$ )

\begin{tabular}{l|c|c|c|c|c|c}
\hline $\begin{array}{c}\text { Hydrochemical } \\
\text { zone }\end{array}$ & Depth, $\mathrm{m}$ & $\mathrm{O}_{2}, \mu \mathrm{M}$ & $\mathrm{H}_{2} \mathrm{~S}, \mu \mathrm{M}$ & $\mathrm{NH}_{4}^{+}, \mu \mathrm{M}$ & $\begin{array}{c}\text { Particulate } \\
\text { matter, } \mu \mathrm{g} / \mathrm{l}\end{array}$ & $\delta^{13} \mathrm{C}, \%_{0}$ \\
\hline I & 40 & 268 & 0 & 0 & 830 & -28.6 \\
$\mathrm{II}$ & 50 & 52 & 0 & 0 & - & - \\
& 60 & 24 & 0 & 0 & 832 & -27.2 \\
& 75 & 15 & 0 & 0 & 673 & -27.7 \\
& 85 & 1 & 0 & 0 & 1320 & -24.9 \\
III & 90 & 1 & 0 & 21.2 & - & - \\
& 105 & 0 & Traces & 55.7 & 1248 & -25.2 \\
IV & 110 & 0 & 0.4 & 70.1 & 1111 & -25.6 \\
& 115 & 0 & 2.2 & 81.4 & 877 & -26.5 \\
& 120 & 0 & 4.5 & 92.0 & 1233 & -27.3 \\
V & 125 & 0 & 6.7 & 95.1 & 1025 & -27.8 \\
& 130 & 0 & 8.9 & 131.8 & 1086 & -27.2 \\
& 135 & 0 & 11.2 & 121.2 & 1020 & -26.9 \\
& 150 & 0 & 15.6 & 171.2 & 900 & -27.5 \\
& 200 & 0 & 31.2 & 248.8 & 1180 & -25.9 \\
& 250 & 0 & 53.5 & 299.2 & - & -25.9 \\
& 300 & 0 & 80.3 & 345.4 & 1010 & -25.7 \\
& 500 & 0 & 174.1 & 605.1 & 1472 & -26.1 \\
& 750 & 0 & 250.0 & 766.5 & 1617 & -26.2 \\
& 1000 & 0 & 276.8 & 743.0 & 695 & -25.8 \\
& 1500 & 0 & 299.0 & 818.8 & 1512 & -27.8 \\
\hline
\end{tabular}

age $\delta^{13} \mathrm{C}$ value is $-26.1 \%$ for the oxycline and $-25.9 \%$ for the upper part of the C-layer (Table 5, zone III). However, comparison of $\delta^{13} \mathrm{C}$ values of the uppermost samples from the C-layer with the $\delta^{13} \mathrm{C}$ values of POC samples from the lower oxycline horizon (Tables 1-3) shows that in the C-layer, the enrichment of POC with the light ${ }^{12} \mathrm{C}$ isotope begins. This process continues in the lower part of the C-layer as far as to the samples containing 6.6-6.7 $\mu \mathrm{M}$ hydrogen sulfide. The average $\delta^{13} \mathrm{C}$ value calculated for 10 samples taken at the three stations in the western part of the sea is $-27.2 \%$ (Tables 1-3 and 5). In samples from the anaerobic zone (with $\mathrm{H}_{2} \mathrm{~S}$ concentrations of $8.9 \mu \mathrm{M}$ and higher), $\mathrm{POC}$ was notably heavier isotopically, having an average $\delta^{13} \mathrm{C}$ value of $-25.7 \%$ (Table 5 , zone V), although at station 5 (Table 3), POC with $\delta^{13} \mathrm{C}$ values from -26.9 to $-27.7 \%$ occurred to a depth of $200 \mathrm{~m}$, i.e., $65 \mathrm{~m}$ below the lower border of the C-layer.

The distribution of $\delta^{13} \mathrm{C}$ values of POC in the eastern part of the sea is somewhat different (Table 4). Considerable lightening of the isotopic composition of POC in the hydrogen sulfide zone $\left(\delta^{13} \mathrm{C}=-27.4 \%\right.$ ) becomes noticeable in samples collected at depths from 135 to $155 \mathrm{~m}$ (at least $25 \mathrm{~m}$ below the upper boundary of the C-layer) and containing more than $10 \mu \mathrm{M} \mathrm{H} \mathrm{H}_{2} \mathrm{~S}$. In deeper horizons of the hydrogen sulfide zone at sta- tion 6, POC becomes isotopically heavier; i.e., the same regularity is observed as at other deep-sea stations.

\section{DISCUSSION}

Figure 3 summarizes data obtained in this work and the results of our determinations of $\delta^{13} \mathrm{C}_{\text {org }}$ values in POC samples collected at northwestern shelf stations during an expedition in the middle of May 1997. It can be seen that our data for POC samples collected in May 1997 and May 1998 were similar to the data of Italian researchers, who collected samples in the second half of April 1997 [17]. Likewise, the results of the analysis of samples that we collected in July 1996 on the northwestern shelf are close to data obtained by Kodina et al. [16] during the analysis of samples collected at the end of September 1992 (Fig. 3, II).

At the same time, POC samples from the upper, oxygenated hydrochemical zone of the central part of the sea, collected at the beginning of May 1998, were found to be considerably enriched with the light ${ }^{12} \mathrm{C}$ isotope as compared to the data of Deuser [18], who analyzed samples collected at the end of March-beginning of April 1969, Fry et al. [15], who took samples at the end of May 1988, and Kodina et al. [16], who ana- 
Table 4. Hydrochemical parameters of the water column and the isotopic composition of POC at station $6\left(43^{\circ} 00^{\prime} 02^{\prime \prime} \mathrm{N}\right.$, $34^{\circ} 30^{\prime} 25^{\prime \prime}$ E; depth, $2123 \mathrm{~m}$ )

\begin{tabular}{c|c|c|c|c|c|c|c}
\hline $\begin{array}{c}\text { Hydrochemical } \\
\text { zone }\end{array}$ & Depth, $\mathrm{m}$ & $\mathrm{O}_{2}, \mu \mathrm{M}$ & $\mathrm{H}_{2} \mathrm{~S}, \mu \mathrm{M}$ & $\mathrm{NH}_{4}^{+}, \mu \mathrm{M}$ & $\mathrm{NO}_{3}^{-}, \mu \mathrm{M}$ & $\begin{array}{c}\text { Particulate } \\
\text { matter, } \mu \mathrm{g} / 1\end{array}$ & $\delta^{13} \mathrm{C}, \% o$ \\
\hline I & 30 & 308 & 0 & 0 & 0.103 & 902 & -29.2 \\
II & 40 & 322 & 0 & 0 & 0.138 & 1163 & $-27.1^{*}$ \\
& 60 & 305 & 0 & 0 & 3.086 & - & - \\
III & 80 & 29 & 0 & 0 & 3.571 & - & - \\
IV & 100 & 11 & 0 & 0 & 1.954 & 932 & -26.6 \\
& 110 & 9 & Traces & 0 & 0.193 & - & - \\
V & 115 & 0 & 2.2 & 0 & 0.127 & - & - \\
& 120 & 0 & 6.6 & - & - & 1780 & -25.6 \\
& 135 & 0 & - & 93.854 & 0 & 2450 & -26.8 \\
& 145 & 0 & - & - & - & 1536 & -27.3 \\
& 150 & 0 & 15.6 & 99.738 & 0 & 1445 & -27.4 \\
& 155 & 0 & - & - & - & 1434 & -27.6 \\
& 200 & 0 & 31.2 & 260.458 & 0 & 1477 & -25.0 \\
& 250 & 0 & - & 379.213 & 0 & 925 & -22.8 \\
& 300 & 0 & 89.3 & 456.871 & 0 & 1129 & -25.0 \\
& 500 & 0 & 156.2 & 525.436 & 0 & 559 & -25.8 \\
& 750 & 0 & 245.5 & 862.442 & 0 & 566 & -25.8 \\
& 1000 & 0 & 290.2 & 1263.641 & 0 & 1225 & -26.0 \\
& 1500 & 0 & 312.5 & 1378.603 & 0 & 918 & -25.7 \\
& 1700 & 0 & - & 1434.819 & 0 & 1088 & -26.5 \\
\hline
\end{tabular}

Table 5. Variation ranges and average values of the $\mathrm{POC} \delta^{13} \mathrm{C}$ in various hydrochemical zones of the deep-water part (I-V) and northwestern shelf (VI) of the Black Sea

\begin{tabular}{|c|c|c|c|c|}
\hline \multirow{2}{*}{$\begin{array}{l}\text { Hydro- } \\
\text { chemical } \\
\text { zones }\end{array}$} & \multirow{2}{*}{ Characteristics of the zones } & \multirow{2}{*}{$\begin{array}{l}\text { Designations of stations* } \\
\text { and samples (parenthesized) }\end{array}$} & \multicolumn{2}{|c|}{$\delta C^{13}, \% o$} \\
\hline & & & range & average \\
\hline I & $\begin{array}{l}\text { Upper oxygenated zone }(0-40 \mathrm{~m}) \text {. } \\
\mathrm{O}_{2} \text { content }>200 \mu \mathrm{M}\end{array}$ & $\begin{array}{l}\text { st. } 23(1), \text { st. } 4(1,2), \text { st. } 5(1), \text { st. } 6(1,2) \\
\text { A total of six samples }\end{array}$ & $-24.2 \ldots-30.2$ & -28.0 \\
\hline II & Oxycline. $\mathrm{O}_{2}$ content from 0 to $174 \mu \mathrm{M}$ & $\begin{array}{l}\text { st. } 3(2,4) \text {, st. } 4(4-6), \text { st. } 5(3-5), \text { st. } 6(5) \\
\text { A total of nine samples }\end{array}$ & $-22.8 \ldots-27.7$ & -26.1 \\
\hline III & $\begin{array}{l}\text { Upper part of the } \mathrm{C} \text {-layer. } \\
\mathrm{H}_{2} \mathrm{~S} \text { content }<0.2 \mu \mathrm{M}\end{array}$ & $\begin{array}{l}\text { st. } 3(5), \text { st. } 4(7), \text { st. } 5(7,8) \\
\text { A total of four samples }\end{array}$ & $-25.2 \ldots-27.0$ & -25.9 \\
\hline IV & $\begin{array}{l}\text { Lower part of the C-layer. } \\
\mathrm{H}_{2} \mathrm{~S} \text { content }>6.7 \mu \mathrm{M}\end{array}$ & $\begin{array}{l}\text { st. } 3(6-8), \text { st. } 4(8-10), \text { st. } 5(9-12) \\
\text { A total of ten samples }\end{array}$ & $-26.5 \ldots-27.8$ & -27.2 \\
\hline $\mathrm{V}$ & Anaerobic zone. $\mathrm{H}_{2} \mathrm{~S}$ content $>8.9 \mu \mathrm{M}$ & $\begin{array}{l}\text { st. } 3(9-14), \text { st. } 4(12-16), \\
\text { st. } 5(13-21), \text { st. } 6(12-20) \\
\text { A total of } 27 \text { samples }\end{array}$ & $-22.8 \ldots-27.8$ & -25.7 \\
\hline VI & $\begin{array}{l}\text { Oxygenated zone on the northwestern shelf. } \\
\mathrm{O}_{2} \text { content }>250 \mu \mathrm{M}\end{array}$ & $\begin{array}{l}\text { st. 1a (2), st. 1b (1), st. } 2(2) \\
\text { A total of five samples }\end{array}$ & $-24.2 \ldots-27.1$ & -25.3 \\
\hline
\end{tabular}

* See Tables 1-4. 
lyzed samples collected at the end of September-beginning of October 1992 (Fig. 3, III).

The considerable differences between our data and the results of earlier research can be explained by the facts that we collected samples in a season when enormous amounts of terrigenic $\mathrm{POC}$ with $\delta^{13} \mathrm{C}$ values from -25.0 to $-31.5 \%$ were brought with flood waters of the Danube River (see Fig. 3, I) and that the intensity of photosynthesis at that time (the beginning of May) was low (Fig. 4). All other researchers analyzed samples of POC dominated by substances of planktonogenic origin. Thus, Deuser [18] analyzed samples collected at the peak of the spring bloom (Fig. 4, March-beginning of April), and Fry and coworkers [15] and Kodina and coworkers [16] collected samples at the end of May and the end of September, i.e., during the summer bloom (Fig. 4) and in a period when the inflow of terrigenic material is considerably reduced as compared to the end of spring.

As can be seen from data presented in Fig. 3, the greatest differences in the isotopic composition of POC in spring, when it is mainly terrigenic, and in summer, when it is primarily planktonogenic, is observed on the shallow-water northwestern shelf, where even the ranges of the $\delta^{13} \mathrm{C}$ values recorded did not overlap: $-22.3 \ldots-30.9 \%$ or the spring terrigenic POC and $-19.8 \ldots-22.0 \%$ o for the summer, mainly planktonogenic, POC (Fig. 3, II).

However, it should be emphasized that the considerable difference in the isotopic composition of POC in spring and summer is recorded not only in the upper hydrochemical zone (Fig. 3, III) but also in the central part of the sea to a depth of at least $200 \mathrm{~m}$ (Fig. 3, IV and V); only in the deep part of the hydrogen sulfide zone does the homogenization of the isotopic composition of POC of different origin occur (Fig. 3, VI).

Thus, the first and, it should be said, unexpected conclusion from the work performed was the existence of seasonable variability of the isotopic composition of POC; this variability is determined by the predominance in the composition of POC of isotopically light terrigenic organic matter in late spring and by the accumulation of isotopically heavier planktonogenic POC in the upper hydrochemical zone as a result of plankton bloom in early spring and summer. It should be mentioned that changes in the $\delta^{13} \mathrm{C}$ value of the POC of surface waters may also occur even in the open ocean, where a significant inflow of terrigenic POC is hardly possible. Such a case is described in the work by Rau $e t$ al. [20], who analyzed the isotopic composition of POC in samples collected over a month at 4-day intervals in the course of the JGOFS NABO international experiment $[20,21]$. During the period of observations, the $\delta^{13} \mathrm{C}$ value of POC changed from $-22.8 \%$ in samples taken on April 24 to $-18.2 \%$ in samples taken on May 30 . These significant changes, occurring in the period of the spring bloom, were not plausibly explained in physicochemical terms, since, in Altabet's opinion

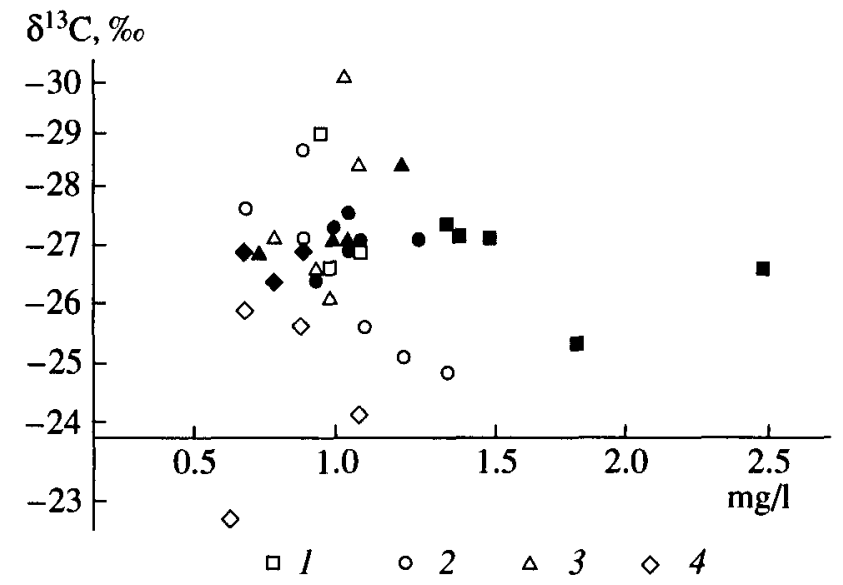

Fig. 2. The amount of particulate matter $(\mathrm{mg} / \mathrm{l})$ and the isotopic composition of POC $\left(\delta^{13} \mathrm{C}\right)$ in the oxygenated zone (open symbols) and hydrogen sulfide zone (filled symbols) of the Black Sea. 1 , st. $6 ; 2$, st. $5 ; 3$, st. $4 ; 4$, st. 3 .

[21], the changes that occurred during the observation period in the concentration of dissolved carbon dioxide and the temperature were too small. In our opinion, the weighting of the isotopic composition of the carbon of phytoplankton biomass occurred due to an increase in the rate of photosynthesis.

Considerable seasonal variations of the $\mathrm{POC} \delta^{13} \mathrm{C}$ in surface waters of the Black Sea, observable not only at the level of extreme values $(-21.4 \%$ in September and $-30.2 \%$ at the beginning of May) but also at the level of averaged values $(-24.3 \%$ in September and $-28.7 \%$ in May, see Fig. 3), should be taken into account during interpretation of the variations in the isotopic composition of POC collected from various hydrochemical zones of the Black Sea.

As an example, let us consider the data on the variations in the isotopic composition of POC in the water column upper part, consisting of the zone of photosynthesis and the oxycline. In all vertical profiles studied so far, a considerable decrease in the content of POC was observed in the direction from the surface to the upper boundary of the hydrogen sulfide zone; this decrease was accompanied by changes in the POC $\delta^{13} \mathrm{C}$ values (see Tables $1-5$ and the data in papers $[15,16]$ ).

In POC samples studied by us and American researchers, weighting of the isotopic composition with depth was observed, whereas at stations investigated by Kodina et al. [16], the isotopic composition of POC of deep-sea samples was characterized by a higher content of the ${ }^{12} \mathrm{C}$ isotope. For example, at station 4 , the difference between $\delta^{13} \mathrm{C}$ values for samples taken from a depth of $35 \mathrm{~m}$ (the middle part of the photosynthesis zone) and $90 \mathrm{~m}$ (the lower part of the oxycline) was $+4 \%$ o ( -30.2 and $-26.2 \%$, respectively). At station 3724 , located in the southeastern part of the deep-sea trough (see Fig. 1), the difference between the $\delta^{13} \mathrm{C}$ values for samples taken from the surface and from a depth of $135 \mathrm{~m}$ 


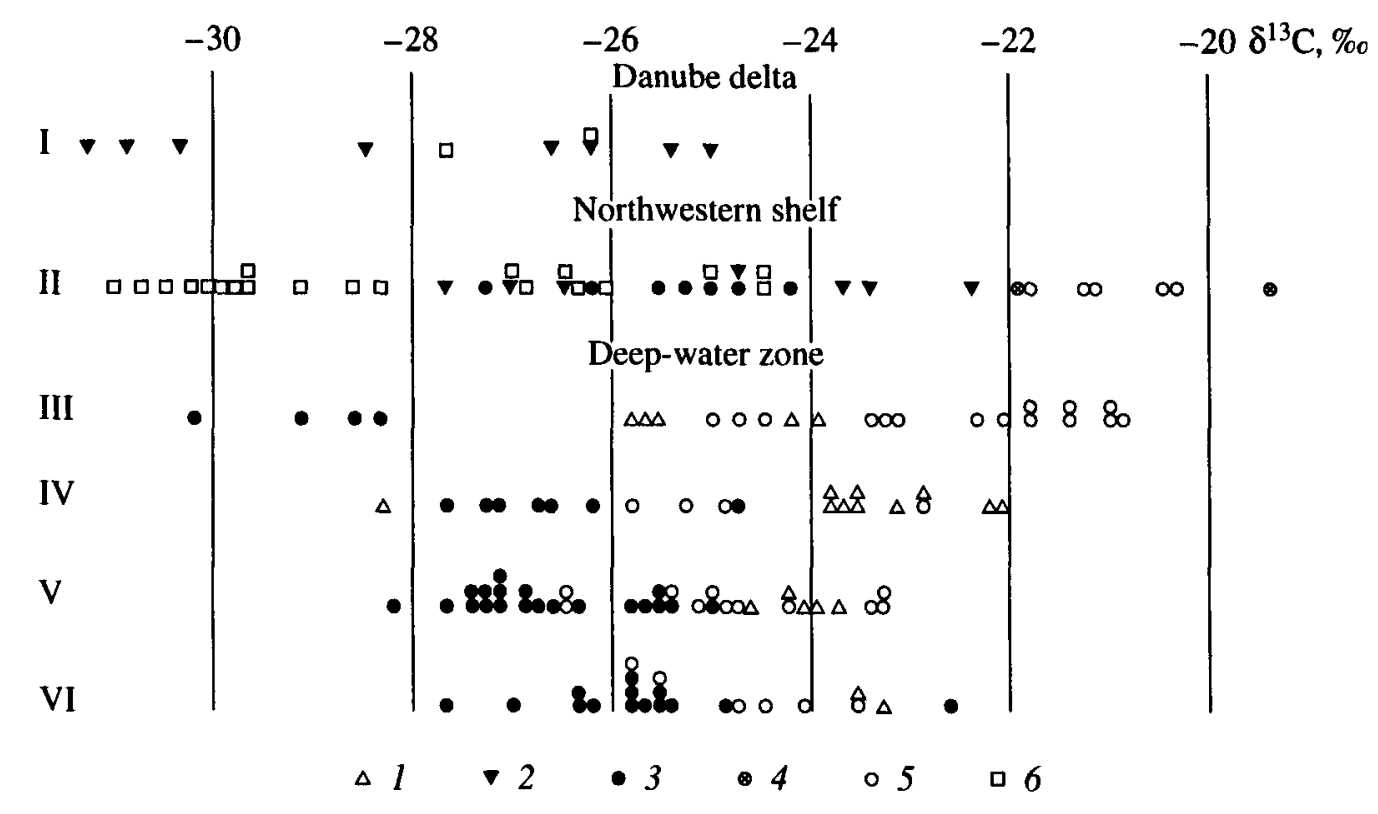

Fig. 3. The isotopic composition of POC $\left(\delta^{13} \mathrm{C}\right)$ of the Black Sea. I, Danube delta, April 1995; II, northwestern shelf; III-VI, central part of the sea: III, photosynthesis zone; IV, oxycline; V, hydrogen sulfide zone to a depth of $200 \mathrm{~m}$; VI, hydrogen sulfide zone below $200 \mathrm{~m}$. 1, the end of May 1988 [15]; 2, April 1997 [17]; 3, the beginning of May 1998 (our data); 4, July 1995 (our data); 5, September-October 1992 [16]; 6, May 1997 (our data).

(15 $\mathrm{m}$ from the boundary of the $\mathrm{H}_{2} \mathrm{~S}$ zone) reached $+4.3 \%$ ( $(-21.5$ and $-25.8 \%)[16]$.

The decrease in the concentration of POC occurring during its sedimentation from the photosynthesis zone can easily be explained by the consumption of a part of organic matter by heterotrophic organisms. However, no fractionation of stable carbon isotopes occurs in this process. Taking into account data on the seasonal variation of the POC $\delta^{13} \mathrm{C}$ value in the zone of photosynthesis (see Fig. 3, II, III, and Fig. 4), it is evident that the isotopic composition of the POC in the oxycline should more or less significantly differ from that in overlying waters, since the oxycline POC is formed several weeks

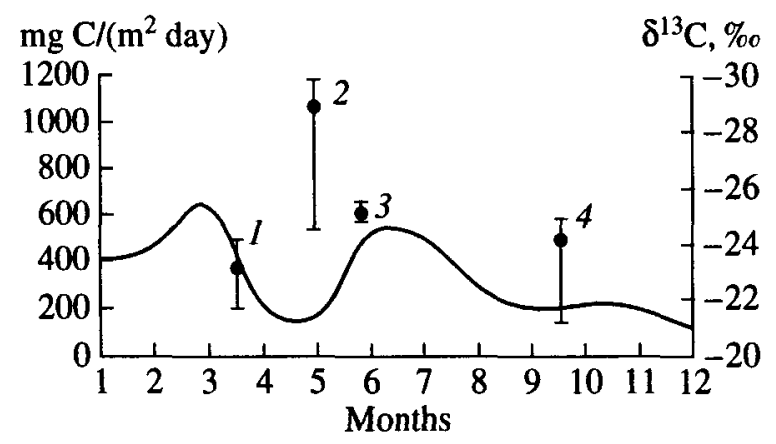

Fig. 4. Seasonal variations in the primary productivity $\left(P, \mathrm{mg} \mathrm{C} /\left(\mathrm{m}^{2}\right.\right.$ day $\left.)\right)$ in the western part of the deep-water basin of the Black Sea [19] and in the isotopic composition of POC $\left(\delta^{13} \mathrm{C}\right.$ ranges and average values) taken from the photosynthesis zone (1) in March-April 1969 [18], (2) at the beginning of May 1998 (our data), (3) at the end of May 1988 [15], and (4) at the end of September-beginning of October 1992 [16]. earlier, when photosynthesis occurs under different conditions, which could influence the $\delta^{13} \mathrm{C}$ value of the organic matter of phytoplankton.

Therefore, the considerable weighting of the isotopic composition of POC in samples that we collected at the beginning of May across the profile of the photosynthesis zone and the oxycline (Table 5) can easily be explained by the fact that in March-April, the isotopic composition of the phytoplankton and POC was essentially different in surface waters (see Fig. 4).

Likewise, it is easy to explain the progressive lightening of the isotopic composition found by Kodina et al. [16] in deep-sea samples at station 3794 . In surface samples, the $\delta^{13} \mathrm{C}$ value was $-21.5 \ldots-22.3 \%$, whereas, at depths of 1500 and $2000 \mathrm{~m}$, the POC $\delta^{13} \mathrm{C}$ equaled -25.5 and $-25.8 \%$. Interestingly, deep-sea samples had practically the same isotopic composition as that of May phytoplankton [15], which sank to deepsea horizons after dying off.

The most interesting data are those on the isotopic composition of POC taken from the C-layer, which is characterized by conditions favorable for the activity of chemolithoautotrophic bacteria involved in the sulfur and nitrogen cycles and also for aerobic methane-oxidizing bacteria. As can be seen from Tables 1-3 and Fig. 5, a slight enrichment of POC with the light ${ }^{12} \mathrm{C}$ isotope can be recorded already $5 \mathrm{~m}$ below the upper detection limit of hydrogen sulfide. A progressive decrease in the $\delta^{13} \mathrm{C}$ value of POC occurs at these stations until the lower boundary of the C-layer, which, based on the data available in the literature, we draw in water layers with an $\mathrm{H}_{2} \mathrm{~S}$ concentration of $6.6-6.8 \mu \mathrm{M}$. Under conditions of a higher hydrogen sulfide concen- 

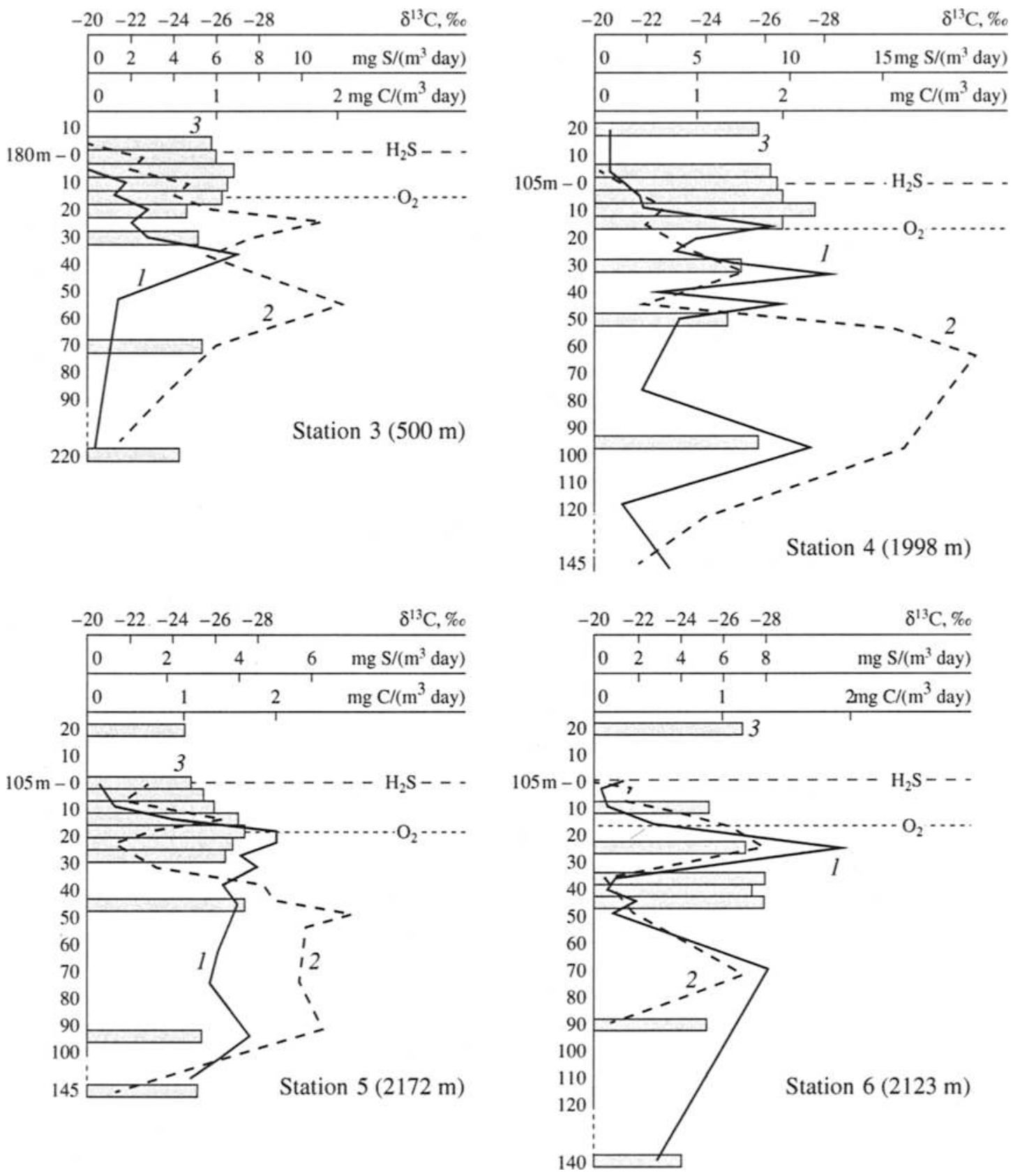

Fig. 5. Vertical distribution of the rates of $(l)$ dark $\mathrm{CO}_{2}$ assimilation $\left(\mathrm{mg} \mathrm{C} /\left(\mathrm{m}^{3}\right.\right.$ day)) and (2) sulfate reduction $\left(\mathrm{mg} \mathrm{S} /\left(\mathrm{m}^{3} \mathrm{day}\right)\right)$ and (3) of the POC $\delta^{13} \mathrm{C}$ values in the upper part of the Black Sea hydrogen sulfide zone. The upper boundary of the occurrence of $\mathrm{H}_{2} \mathrm{~S}$ was taken as the zero point.

tration and a complete lack of oxygen, the $\delta^{13} \mathrm{C}$ values of POC gradually increase (Tables 1-3, 5 and Fig. 5). Figure 5 presents data on the isotopic composition of carbon and the rate of dark assimilation of $\mathrm{CO}_{2}$ [6]. At all three stations of the western part of the Black Sea (stations 3-5, Tables 1-3), the rate of dark assimilation of $\mathrm{CO}_{2}$ increases with depth within the $\mathrm{C}$-layer, and the upper peak of $\mathrm{CO}_{2}$ fixation coincides with the lowest values of $\delta^{13} \mathrm{C}$.

We consider the combination of conditions favorable for the development of aerobic $\mathrm{H}_{2} \mathrm{~S}$-oxidizing bac- teria, the gradual increase in the $\mathrm{CO}_{2}$ fixation rate, and considerable change in the $\delta^{13} \mathrm{C}$ values of $\mathrm{POC}$ as compared to overlying waters to be sufficient proof of the role of chemosynthesis in the change of the isotopic composition of POC. This is most evident from data for station 5 (Table 3, Fig. 5), where we recorded the highest rate of $\mathrm{CO}_{2}$ fixation and maximum enrichment of POC with the ${ }^{12} \mathrm{C}$ isotope (as compared to the oxycline waters).

Unfortunately, at station 6 , we failed to analyze a sufficient number of samples from the C-layer; how- 
ever, immediately below this layer, in waters containing at least $10.5 \mu \mathrm{M} \mathrm{H}_{2} \mathrm{~S}$, there occurs a pronounced peak of low $\delta^{13} \mathrm{C}$ values of POC (it was recorded at a depth of 135-155 m, Table 4). Aerobic chemosynthesis is impossible under these conditions; therefore, we think that the isotopically light POC arrives in this horizon from the C-layer, studied insufficiently at this station, or even from surface waters, enriched earlier with terrigenic organic matter. The latter supposition is supported by the unusually high content of POC in water samples taken from these water column horizons at station 6 (see Table 4 and Fig. 2).

The average value of the change in the isotopic composition of POC at the expense of chemosynthesis in the lower part of the C-layer at stations 3-5 equals $-1.3 \%$ as compared to the overlying horizon of the water column (Table 5). Analysis of the equation of matter-isotope balance with the use of the fractionation rate characteristic of chemosynthesis in the cultures of chemoautotrophs $(-39.5 \%)$ [13] shows that about $11 \%$ of newly formed organic matter is formed in the process of chemosynthesis as the biomass of chemoautotrophic bacteria.

Comparing our results with the results of Kodina $e t$ al. [16], we have to make several critical comments concerning the interpretation of isotopic data by the latter authors. In each of the four vertical profiles of the water column, from the surface to a depth of $200 \mathrm{~m}$, the authors paid attention to four samples having the lightest POC and stated that in these samples, the isotopic composition had been changed due to the activity of the chemoautotrophic bacteria of the sulfur cycle. The authors neglect the fact that two of these four samples (stations 3794 and 3801, see Fig. 1) were taken 15 and $20 \mathrm{~m}$ above the upper boundary of hydrogen sulfide waters, where the energy substrate for chemoautotrophic bacteria of the sulfur cycle-hydrogen sulfide -is lacking, which precludes the development of these bacteria and thus their involvement in carbon isotope fractionation.

For two other samples, one of which (st. 3818) was taken from the upper boundary of the hydrogen sulfide layer and the other one (st. 3804), $25 \mathrm{~m}$ below this boundary, no evidence for active chemosynthesis was presented except references to microbiological works performed in other years, other seasons, and other Black Sea sites.

The method that the authors suggest for the calculation of the isotopic effect of chemosynthesis within the -4 to $-5 \%$ range is quite embarrassing [16]. This value was obtained by comparing $\delta^{13} \mathrm{C}$ values of $\mathrm{POC}$ from the chemosynthesis zone and POC of surface waters; the distance between the sampling sites was 85-170 m. The actual enrichment, as compared with the closest samples at three stations, was $0.3 \ldots 0.9 \%$, and only at station 3818 did the isotopically lightest sample differ from the neighboring sample taken $50 \mathrm{~m}$ above by $3.7 \%$. It should be said that, after we found a consider- able difference between $\delta^{13} \mathrm{C}$ values in samples taken $5 \mathrm{~m}$ apart (Tables 1-4), it is difficult to speak about the successful search for regularities when samples are taken at the boundary of aerobic and anaerobic waters at $35-50 \mathrm{~m}$ intervals [16].

An issue deserving separate discussion is the considerable change in the isotopic composition of $\mathrm{POC}$ in the strictly anaerobic zone located below the C-layer. As follows from data presented in Tables 1-5 and Fig. 5, weighting of the POC isotopic composition occurred with depth along all profiles. This suggests the disappearance of the organic matter of the biomass of chemoautotrophic bacteria enriched with the light carbon isotope. We believe that this organic matter is consumed by the community of anaerobic heterotrophic bacteria. Direct evidence in favor of this interpretation is data on the distribution of the intensity of sulfate reduction. As can be seen from Fig. 5, at all stations this process peaked below the C-layer.

Finally, in deeper horizons of the hydrogen sulfide zone of the sea, where, due to a shortage of easily available organic matter, all microbial processes occur at minimal rates $[4,6]$, the isotopic composition of POC virtually does not change (Tables $1-4$ ).

Thus, a detailed study of the isotopic composition of POC, together with microbiological and biogeochemical investigations carried out simultaneously, allowed us to prove categorically that chemoautotrophic bacteria developing in the zone of coexistence of $\mathrm{H}_{2} \mathrm{~S}$ and $\mathrm{O}_{2}$ not only produce organic matter in the form of biomass but also exert a considerable influence on the isotopic composition of POC.

\section{CONCLUSION}

(1) Seasonal variations in the isotopic composition of POC were discovered, which depended on the amounts of terrigenic and planktonogenic organic matter in the composition of the total POC.

(2) Based on the analysis of data on the rates of bacterial fixation of $\mathrm{CO}_{2}$, hydrochemical data, and the $\delta^{13} \mathrm{C}$ values of $\mathrm{POC}$, it may be considered proven that bacterial chemosynthesis occurs in the C-layer and that this process affects the isotopic composition of POC.

(3) Enrichment of the POC of the anaerobic zone below the C-layer with the ${ }^{13} \mathrm{C}$ isotope is due to the preferential consumption of newly formed isotopically light biomass of chemoautotrophs by the heterotrophic bacterial community, primarily by sulfate reducers.

\section{ACKNOWLEDGMENTS}

We are grateful to the crew of the research vessel Professor Vodyanitskii for their help with the bathymetry work. We are particularly grateful to V.N. Egorov, S.B. Gulin, and Yu.G. Artemov for organizing the international expedition. 
This work was supported by the Russian Foundation for Basic Research, project no. 00-15-97897, and by the INTAS-RFBR grant no. 95-1067.

\section{REFERENCES}

1. Kuznetsov, S.I., Mikroflora ozer i ee geokhimicheskaya deyatel'nost' (Lake Microflora and Its Geochemical Activity), Leningrad: Nauka, 1970.

2. Jorgensen, B.B., Processes at the Sediment-Water Interface, The Major Biogeochemical Cycles and Their Interaction, Bolin, B. and Cook, R.B., Eds., New York: Wiley, 1983, pp. 477-508.

3. Skopintsev, B.A., Formirovanie sovremennogo khimicheskogo sostava vod Chernogo morya (Formation of the Modern Chemical Composition of the Black Sea Waters), Leningrad: Gidrometizdat, 1975.

4. Sorokin, Yu.A., Chernoe more: Priroda, resursy (The Black Sea), Moscow: Nauka, 1982.

5. Sorokin, Yu.I. and Avdeev, V.A., Bacterial Production and Bacterial Chemosynthesis, Izmenchivost' ekosistemy Chernogo morya: estestvennye i antropogennye faktory (Variability of the Black Sea Ecosystem: Natural and Anthropogenic Factors), Moscow: Nauka, 1991, pp. 46-52.

6. Pimenov, N.V., Rusanov, I.I., Yusupov, S.K., Fridrich, J., Lein, A.Yu., Wehrli, B., and Ivanov, M.V., Microbial Processes at the Aerobic-Anaerobic Interface in the Deep-Water Zone of the Black Sea, Mikrobiologiya, 2000, vol. 69, no. 4, pp. 527-540.

7. Repeta, D.J. and Simpson, D.J., Distribution and Recycling of Chlorophyll, Bacteriochlorophyll, and Carotenoids in the Black Sea, Black Sea Oceanogr., Deep Sea Res., 1991, vol. 38, suppl. issue 2A, pp. 969-984.

8. Overmann, J., Cypionka, H., and Pfennig, N., An Extremely Low-Light-adapted Phototrophic Sulfur Bacterium from the Black Sea, Limnol. Oceanogr., 1992, vol. 37, no. 1, pp. 150-155.

9. Rusanov, I.I., Savvichev, A.S., Yusupov, S.K., Pimenov, N.V., and Ivanov, M.V., Production of Exometabolites in the Microbial Oxidation of Methane in Marine Ecosystems, Mikrobiologiya, 1998, vol. 67, no. 5, pp. 710-717.

10. Gogotova, G.I., Galimov, E.M., and Ivanov, M.V., Fractionation of Stable Carbon Isotopes by Phototrophic Sulfur Bacteria, Dokl. Akad. Nauk SSSR, 1973, vol. 208, no. 3, pp. 432-435.

11. Degens, E.T., Biogeochemistry of Stable Carbon Isotopes, Organic Geochemistry, Eglington, E. and Mur- phy, M.J.T., Eds., New York: Springer-Verlag, 1969, pp. 304-329.

12. Sierevag, R., Buchanan, B.B., Berry, J.A., and Troughton, J.M., Mechanisms of $\mathrm{CO}_{2}$ Fixation in Bacterial Photosynthesis Studied by the Carbon Isotope Fractionation Technique, Arch. Microbiol., 1977, vol. 112, no. 1, pp. 35-38.

13. Ruby, E.G., Jannasch, H.W., and Deuser, W.O., Fractionation of Stable Carbon Isotopes during Chemoautotrophic Growth of Sulfur-oxidizing Bacteria, Appl. Environ. Microbiol., 1987, vol. 53, no. 8, pp. 19401943.

14. Ivanov, M.V., Polikarpov, G.G., Lein, A.Yu., Gal'chenko, V.F., Egorov, V.N., Gulin, S.B., Gulin, M.B., Rusanov, I.I., Miller, Yu.M., and Kuptsov, V.I., Biogeochemistry of the Carbon Cycle in the Zone of Methane Seeps in the Black Sea, Dokl. Akad. Nauk SSSR, 1991, vol. 320, no. 5, pp. 1235-1240.

15. Fry, B., Jannasch, H.W., Molyneaux, S.J., Wirsen, C.O., Muramoto, J.A., and King, S., Stable Isotope Studies of the Carbon, Nitrogen, and Sulfur Cycles in the Black Sea and the Cariaco Trench, Black Sea Oceanogr., Deep Sea Res., 1991, vol. 38, suppl. issue 2A, pp. 1003-1019.

16. Kodina, L.A., Bogacheva, M.P., and Lyutsarev, S.V., Particulate Organic Carbon in the Black Sea: Isotopic Composition and Nature, Geokhimiya, 1996, no. 9, pp. 884890.

17. Breas, O., Guillon, C., Lancelot, C., Martin, J.M., Mousty, F., and Raniero, E., Measurement of ${ }^{13} \mathrm{C} /{ }^{12} \mathrm{C}$ of Particulate and Dissolved Organic Matter in the Black Sea and Danube River, Estuarine, Coastal, Shelf Sci., 2000 (in press).

18. Deuser, W.G., Isotopic Evidence for Diminishing Supply of Available Carbon during Diatom Bloom in the Black Sea, Nature, 1970, vol. 225, pp. 1069-1071.

19. Bologa, A.S., Frangopol, P.T., Vedernikov, V.I., Stelmakh, I.V., Yunev, O.A., Yilmas, A., and Oguz, T., Distribution of Planktonic Primary Production in the Black Sea, Environmental Degradation of the Black Sea: Challenges and Remedies, Bucharest, 1999, pp. 131-146.

20. Rau, G.H., Takahashi, D.J., Des-Mardis, D., Repeta, D.J., and Martin, J.H., The Relationship between the ${ }^{13} \mathrm{C}$ of Organic Matter and $\left\{\mathrm{CO}_{2(\mathrm{aq})}\right\}$ in Ocean Surface Water, Geochem. Cosmochem. Acta, 1992, vol. 56, pp. 14131419.

21. Altabet, M.A., Nitrogen and Carbon Isotope Traces of the Source and Transformation of Particles in the Deep Sea, Particle Flux in the Ocean, New York: Wiley, 1996, pp. 155-184. 